\title{
Triflic Anhydride-Mediated Beckmann Rearrangement Reaction of $\beta$-Oximyl Amides: Access to 5-Iminooxazolines
}

\author{
MANGFEI YU ${ }^{\mathrm{a}}$, QIAN ZHANG ${ }^{\mathrm{b}}$, JIA WANG $^{\mathrm{b}}$, PENG HUANG $^{\mathrm{b}}$, PENGFEI YAN $^{\mathrm{a}, *}$, \\ RUI ZHANG ${ }^{\mathrm{b}}$ and DEWEN DONG ${ }^{\mathrm{b}, *}$ \\ ${ }^{a}$ School of Chemistry and Materials Science, Heilongjiang University, Harbin 150080, China \\ ${ }^{\mathrm{b}}$ Key Laboratory of Synthetic Rubber, Changchun Institute of Applied Chemistry, \\ Chinese Academy of Sciences, Changchun 130022, China \\ e-mail: yanpf@vip.sina.com; dwdong@ciac.ac.cn
}

MS received 19 January 2016; revised 14 March 2016; accepted 27 March 2016

\begin{abstract}
Facile and efficient synthesis of 5-iminooxazolines from $\alpha, \alpha$-disubstituted $\beta$-oximyl amides mediated by triflic anhydride $\left(\mathrm{Tf}_{2} \mathrm{O}\right)$ in the presence of 1,8-diazabicyclo(5.4.0)undec-7-ene (DBU) in dichloromethane at room temperature is developed, and a mechanism involving tandem Beckmann rearrangement and intramolecular cyclization reaction is proposed.
\end{abstract}

Keywords. Beckmann rearrangement; cyclization; $\beta$-oximyl amides; oxazolines; triflic anhydride.

\section{Introduction}

The rearrangement of ketoximes to the corresponding amides, known as the Beckmann reaction, is a classical transformation in organic chemistry and continues to be an active area of current research. ${ }^{1}$ In chemical industry, it is successfully employed as a powerful tool for the manufacturing $\varepsilon$-caprolactam. ${ }^{2}$ Unfortunately, the conventional Beckmann rearrangement reaction usually requires strong acid catalysts and harsh conditions, such as high reaction temperature and dehydrating media, which meanwhile releases quite a lot of acidic wastes. ${ }^{1,3}$ Therefore, mild and efficient organocatalysis of the Beckmann rearrangement reaction has been developed to overcome these drawbacks, ${ }^{4-6}$ and some Beckmann rearrangement reactions have been realized in ionic liquids at room temperature ${ }^{7}$ and supercritical water. ${ }^{8}$ Most reported mild conditions were still associated with the use of rather toxic and/or expensive reagents or solvents. ${ }^{1,3}$ The investigation of Beckmann rearrangement reactions with the aim to obtain mild and efficient conditions is still in demand.

During the course our studies on the development of synthetic methodologies for heterocycles from $\beta$-oxo amide derivatives, we prepared a series of $\beta$-oximyl amides $\mathbf{1}$ and investigated their reaction behavior under different conditions, and achieved a divergent synthesis of 5-chloro- $1 \mathrm{H}$-pyrazoles (Path A), ${ }^{9}$ 5-arylamino-4haloethylisoxazoles (Path B and C), ${ }^{9,10}$ and spiro-fused

*For correspondence pyrazolin-5-ones (Path D) ${ }^{10}$ under varied conditions (scheme 1). Contrary to those reported Beckmann rearrangement reactions mediated or catalyzed by the activation of the hydroxyl group by the $p$-toluenesulfonyl or cyanuric chloride, ${ }^{4,11}$ the Beckmann rearrangement reaction of $\beta$-oximyl amides $\mathbf{1}$ was not observed under our tested conditions as described in scheme 1 . Very recently, we developed a facile synthesis of 2,3dihydrofuro[3,2-c]pyridin-4(5H)-ones by the reaction of 1-aminopropenoyl cyclopropane-1-carboxamides in the presence of triflic anhydride $\left(\mathrm{Tf}_{2} \mathrm{O}\right){ }^{12}$ In connection with these studies and our continuing interest in the further synthetic potential of $\beta$-oximyl amides $\mathbf{1}$, we investigated their reactivity toward triflic anhydride and other organic anhydrides under different conditions. As a result of this study, we achieved an efficient synthesis of 5-iminooxazolines 2 (scheme 1, Path E) under very mild conditions. In the present work, we wish to report our experimental results and present a proposed mechanism involved.

\section{Experimental}

\subsection{Reagents and Instrumentation}

All reagents were purchased from commercial sources and used without purification, unless otherwise indicated. ${ }^{1} \mathrm{H}$ NMR and ${ }^{13} \mathrm{C}$ NMR spectra were recorded at $25^{\circ} \mathrm{C}$ at $300 \mathrm{MHz}$ (or $400 \mathrm{MHz}$ ) and $100 \mathrm{MHz}$, respectively, with TMS as internal standard. IR spectra ( $\mathrm{KBr})$ were recorded on FTIR-spectrophotometer in the range 


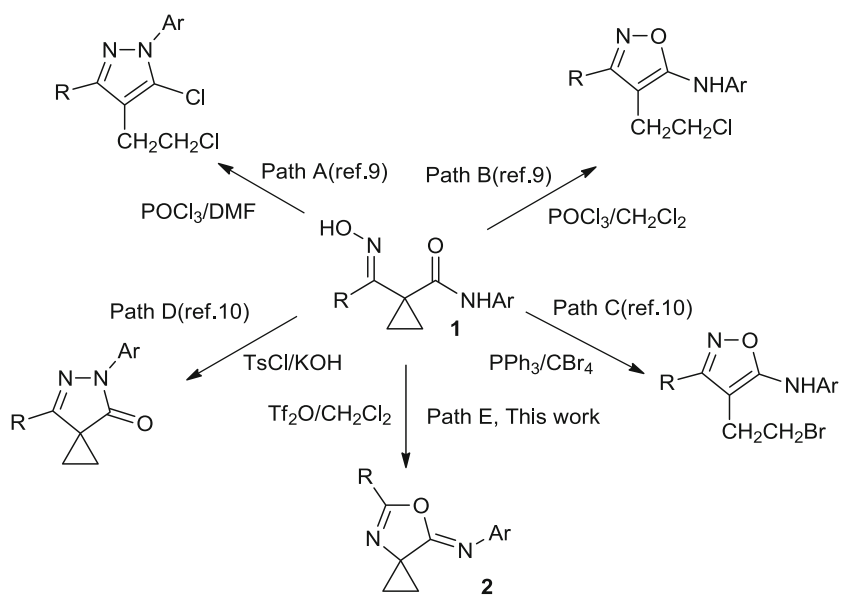

Scheme 1. Reactions of $\alpha$-Carbamoyl- $\alpha$-Oximyl Cyclopropanes 1 under different conditions.

of $400-4000 \mathrm{~cm}^{-1}$. Melting points were uncorrected. All reactions were monitored by TLC with GF254 silica gel-coated plates. Chromatography was carried out on silica gel (300-400 mesh).

2.2 Typical procedure for the synthesis of 2 (2a as an example)

To a solution of $1 \mathrm{a}(1.0 \mathrm{mmol})$ in DCM $(5 \mathrm{~mL})$ at room temperature was added $\mathrm{Tf}_{2} \mathrm{O}(1.2 \mathrm{mmol})$ and $\mathrm{DBU}(1.2$ $\mathrm{mmol})$ in one portion. The mixture was stirred at room temperature for $15 \mathrm{~min}$, and then poured into brine (15 $\mathrm{mL})$, which was extracted with DCM $(3 \times 10 \mathrm{~mL})$. The combined organic phases were washed with water $(2 \times$ $10 \mathrm{~mL}$ ), dried over $\mathrm{MgSO}_{4}$, filtered and concentrated in vacuo. The crude product was purified by flash chromatography (silica gel, petroleum ether : ethyl acetate $=10: 1)$ to give $2 \mathbf{a}$ as a white solid $(0.208 \mathrm{~g}, 89 \%)$.

\subsection{Physical Data of Compounds $\mathbf{2}$ and $\mathbf{3}$}

2a, 2c, $\mathbf{2 d}, \mathbf{2 f}, \mathbf{2 h}, \mathbf{2 i}$ are known compounds, and their analytical data are in good agreement with those in literature [see ref. 14].

2.3a (Z)-4-Chloro-N-(5-methyl-6-oxa-4-azaspiro[2.4] hept-4-en-7-ylidene)aniline (2a): White solid, M.p. $179-181{ }^{\circ} \mathrm{C} ;{ }^{1} \mathrm{H}$ NMR $\left(400 \mathrm{MHz}, \mathrm{CDCl}_{3}\right): \delta=1.55(\mathrm{t}$, $J=3.6 \mathrm{~Hz}, 2 \mathrm{H}), 1.63(\mathrm{t}, J=3.6 \mathrm{~Hz}, 2 \mathrm{H}), 2.20(\mathrm{~s}, 3 \mathrm{H})$, $7.06(\mathrm{~d}, J=8.4 \mathrm{~Hz}, 2 \mathrm{H}), 7.26(\mathrm{~d}, J=8.4 \mathrm{~Hz}, 2 \mathrm{H})$; ${ }^{13} \mathrm{C}$ NMR $\left(100 \mathrm{MHz}, \mathrm{CDCl}_{3}\right): \delta=14.9,18.9,49.8$, $124.3,128.8,129.6,143.9,162.1,162.4$; IR (KBr) 3132, 3012, 2931, 1718, 1672, 1598, 1544, 1488, 1402, 1240, 1083, 966, 918, 841, $653 \mathrm{~cm}^{-1}$; Anal. Calcd. for $\mathrm{C}_{12} \mathrm{H}_{11} \mathrm{ClN}_{2} \mathrm{O}$ : C, 61.41; H, 4.72; N, 11.94. Found: C,
61.16; H, 4.80; N, 11.88. MS calcd. $m / z$ 234.1, found $235.1\left[(\mathrm{M}+1)^{+}\right]$.

Colorless crystal, $M=234.68$, Monoclinic, $C 2 / c$, $a=23.827(6) \AA, b=7.4104(19) \AA, c=14.707(4)$ $\AA, \alpha=90.00^{\circ}, \beta=116.100(5)^{\circ}, \gamma=90.00^{\circ}, V=$ 2332.0(11) $\AA^{3}, Z=8, T=293, F_{000}=976, R_{1}=$ $0.0553, w R_{2}=0.2452$.

$2.3 \mathrm{~b}$ (Z)-3-Chloro-N-(5-methyl-6-oxa-4-azaspiro[2.4] hept-4-en-7-ylidene)aniline ( $\mathbf{2 b}$ ): Colorless semi-solid; ${ }^{1} \mathrm{H}$ NMR (400 MHz, $\left.\mathrm{CDCl}_{3}\right): \delta=1.54(\mathrm{t}, J=3.5 \mathrm{~Hz}$, $2 \mathrm{H}), 1.63(\mathrm{~d}, J=3.2,2 \mathrm{H}), 2.18(\mathrm{~s}, 3 \mathrm{H}), 6.98(\mathrm{~d}, J=$ $8.0 \mathrm{~Hz}, 1 \mathrm{H}), 7.06(\mathrm{~d}, J=8.0 \mathrm{~Hz}, 1 \mathrm{H}), 7.12(\mathrm{~s}, 1 \mathrm{H})$, $7.19(\mathrm{~d}, J=8.0 \mathrm{~Hz}, 1 \mathrm{H}) ;{ }^{13} \mathrm{C} \mathrm{NMR}\left(100 \mathrm{MHz}, \mathrm{CDCl}_{3}\right)$ : $\delta=14.8,18.9,49.7,121.1,123.0,124.3,129.6,134.1$, 146.6, 162.0, 162.8. IR (KBr) 3145, 3021, 2938, 1702, 1617, 1488, 1406, 1253, 1038, 1012, 963, 922, 835, 684 $\mathrm{cm}^{-1}$; Anal. Calcd. (\%) for $\mathrm{C}_{12} \mathrm{H}_{11} \mathrm{ClN}_{2} \mathrm{O}$ : C, 61.41; H, 4.72; N, 11.94; Found (\%): C, 61.55; H, 4.75; N, 11.87.

$2.3 \mathrm{c}$ (Z)-2-Methyl-N-(5-methyl-6-oxa-4-azaspiro[2.4] hept-4-en-7-ylidene) aniline (2e): Colorless oil; ${ }^{1} \mathrm{H}$ NMR $\left(400 \mathrm{MHz}, \mathrm{CDCl}_{3}\right): \delta=1.57(\mathrm{t}, J=3.2 \mathrm{~Hz}, 2 \mathrm{H}), 1.64$ $(\mathrm{t}, J=3.2 \mathrm{~Hz}, 2 \mathrm{H}), 2.16(\mathrm{~s}, 3 \mathrm{H}), 2.19$ (s, 3H), 6.97$7.04(\mathrm{~m}, 2 \mathrm{H}), 7.15(\mathrm{~d}, J=7.6 \mathrm{~Hz}, 1 \mathrm{H}), 7.18(\mathrm{~d}, J=$ $7.6 \mathrm{~Hz}, 1 \mathrm{H}) ;{ }^{13} \mathrm{C}$ NMR $\left(100 \mathrm{MHz}, \mathrm{CDCl}_{3}\right): \delta=14.9$, $17.7,18.6,49.1,121.1,124.0,126.0,130.0,130.1$, 144.4, 161.1, 162.4; IR (KBr) 3138, 3014, 2946, 1789, 1721, 1633, 1488, 1425, 1402, 1274, 1039, 1014, 965, 926, 838, $691 \mathrm{~cm}^{-1}$; Anal. Calcd. (\%) for $\mathrm{C}_{13} \mathrm{H}_{14} \mathrm{~N}_{2} \mathrm{O}$ : C, 72.87; H, 6.59; N, 13.07. Found (\%): C, 73.05; H, $6.52 ; \mathrm{N}, 13.02$.

2.3d (Z)-N-(5-Phenyl-6-oxa-4-azaspiro[2.4]hept-4-en7-ylidene)aniline (2g): White solid, M.p. $117-119^{\circ} \mathrm{C}$; ${ }^{1} \mathrm{H}$ NMR $\left(400 \mathrm{MHz}, \mathrm{CDCl}_{3}\right): \delta=1.72\left(\mathrm{dd}, J_{1}=8.0\right.$ $\left.\mathrm{Hz}, J_{2}=4.4 \mathrm{~Hz}, 2 \mathrm{H}\right), 1.82\left(\mathrm{dd}, J_{1}=8.0 \mathrm{~Hz}, J_{2}=4.4\right.$ $\mathrm{Hz}, 2 \mathrm{H}), 7.17(\mathrm{t}, J=7.3 \mathrm{~Hz}, 1 \mathrm{H}), 7.26(\mathrm{~d}, J=9.0 \mathrm{~Hz}$, $2 \mathrm{H}), 7.39$ (t, $J=7.6 \mathrm{~Hz}, 2 \mathrm{H}), 7.46(\mathrm{t}, J=7.6 \mathrm{~Hz}, 2 \mathrm{H})$, $7.53(\mathrm{t}, J=7.3 \mathrm{~Hz}, 1 \mathrm{H}), 7.94(\mathrm{~d}, J=7.3 \mathrm{~Hz}, 2 \mathrm{H}) ;{ }^{13} \mathrm{C}$ NMR $\left(100 \mathrm{MHz}, \mathrm{CDCl}_{3}\right): \delta=19.7,19.8,50.7,123.1$, $124.5,126.4,127.4,128.7,128.8,132.0,145.3,161.2$, 161.6; IR (KBr) 3136, 3018, 2964, 1797, 1712, 1641, 1488, 1422, 1400, 1269, 1039, 1016, 962, 921, 765, $692 \mathrm{~cm}^{-1}$; Anal. Calcd. (\%) for $\mathrm{C}_{17} \mathrm{H}_{14} \mathrm{~N}_{2} \mathrm{O}$ : C, 77.84; H, 5.38; N, 10.68. Found (\%): C, 77.64; H, 5.43; N, 10.75 .

2.3e (Z)-N-(4,4-Diallyl-2-methyloxazol-5(4H)-ylidene) aniline (2j): Colorless oil; ${ }^{1} \mathrm{H}$ NMR $(400 \mathrm{MHz}$, $\left.\mathrm{CDCl}_{3}\right): \delta=1.99(\mathrm{~s}, 3 \mathrm{H}), 2.43-2.48(\mathrm{~m}, 2 \mathrm{H}), 2.64-2.69$ 
(m, 2H), 5.14-5.22 (m, 4H), 5.57-5.67 (m, 2H), 7.10$7.13(\mathrm{~m}, 1 \mathrm{H}), 7.16(\mathrm{~d}, J=7.6 \mathrm{~Hz}, 2 \mathrm{H}), 7.33(\mathrm{t}, J=$ $7.6 \mathrm{~Hz}, 2 \mathrm{H}) ;{ }^{13} \mathrm{C}$ NMR $\left(100 \mathrm{MHz}, \mathrm{CDCl}_{3}\right): \delta=11.0$, 40.5, 58.5, 119.7, 122.6, 124.2, 128.6, 130.9, 145.5, 162.9, 165.0; IR (KBr) 3138, 3022, 2914, 1703, 1618, 1594, 1523, 1485, 1411, 1087, 885, 843, $706 \mathrm{~cm}^{-1}$; Anal. Calcd. (\%) for $\mathrm{C}_{16} \mathrm{H}_{18} \mathrm{~N}_{2} \mathrm{O}: \mathrm{C}, 75.56 ; \mathrm{H}, 7.13 ; \mathrm{N}$, 11.01. Found (\%): C, 75.42; H, 7.17; N, 10.93.

$2.3 \mathrm{f}$ (Z)-N-(2-Methyl-4,4-di(prop-2-yn-1-yl)oxazol5(4H)-ylidene)aniline $(\mathbf{2 k})$ : Colorless oil; ${ }^{1} \mathrm{H}$ NMR $\left(400 \mathrm{MHz}, \mathrm{CDCl}_{3}\right): \delta=2.16-2.17(\mathrm{~m}, 5 \mathrm{H}), 2.71-2.72$ $(\mathrm{m}, 4 \mathrm{H}), 7.15(\mathrm{t}, J=7.2 \mathrm{~Hz}, 1 \mathrm{H}), 7.24(\mathrm{~d}, J=7.6 \mathrm{~Hz}$, $2 \mathrm{H}), 7.36(\mathrm{t}, J=7.6 \mathrm{~Hz}, 2 \mathrm{H}) ;{ }^{13} \mathrm{C} \mathrm{NMR}(100 \mathrm{MHz}$, $\left.\mathrm{CDCl}_{3}\right) \delta=11.3,25.6,57.0,72.3,77.0,122.8,124.6$, 128.6, 144.9, 161.6, 163.8; IR (KBr) 3135, 3027, 2921, 1698, 1609, 1562, 1485, 1403, 1092, 876, 837, 768, $705 \mathrm{~cm}^{-1}$; Anal. Calcd. (\%) for $\mathrm{C}_{16} \mathrm{H}_{14} \mathrm{~N}_{2} \mathrm{O}: \mathrm{C}, 76.78$; H, 5.64; N, 11.19. Found (\%): C, 76.60; H, 5.70; N, 11.29 .

$2.3 \mathrm{~g}$ (Z)-N-(4,4-Dibenzyl-2-methyloxazol-5(4H)ylidene)aniline (2l): White solid, M.p. $102-103^{\circ} \mathrm{C} ;{ }^{1} \mathrm{H}$ NMR $\left(400 \mathrm{MHz}, \mathrm{CDCl}_{3}\right): \delta=2.14(\mathrm{~s}, 3 \mathrm{H}), 3.14(\mathrm{~d}$, $J=13.6 \mathrm{~Hz}, 2 \mathrm{H}), 3.46(\mathrm{~d}, J=13.6 \mathrm{~Hz}, 2 \mathrm{H}), 7.13(\mathrm{t}$, $J=7.2 \mathrm{~Hz}, 3 \mathrm{H}), 7.21-7.30(\mathrm{~m}, 10 \mathrm{H}), 7.33(\mathrm{t}, J=$ $8.0 \mathrm{~Hz}, 2 \mathrm{H}) ;{ }^{13} \mathrm{C}$ NMR $\left(100 \mathrm{MHz}, \mathrm{CDCl}_{3}\right) \delta=12.3$, 43.2, 62.4, 120.0, 122.9, 124.5, 127.5, 128.6, 128.8, $129.4,134.9,136.0,145.3,162.8,164.2$; IR (KBr)
3134, 3029, 2916, 1704, 1591, 1487, 1400, 1085, 871, 840, 777, $703 \mathrm{~cm}^{-1}$; Anal. Calcd. (\%) for $\mathrm{C}_{24} \mathrm{H}_{22} \mathrm{~N}_{2} \mathrm{O}$ : C, 81.33; H, 6.26; N, 7.90. Found (\%): C, 81.52; H, $6.16 ; \mathrm{N}, 7.95$.

2.3h 4-Benzyl-2-methyl-N-phenyloxazol-5-amine (3m): White solid, M.p. $134-137^{\circ} \mathrm{C}$; ${ }^{1} \mathrm{H}$ NMR $(300 \mathrm{MHz}$, $\left.\mathrm{CDCl}_{3}\right): \delta=2.16(\mathrm{~s}, 3 \mathrm{H}), 3.65(\mathrm{~s}, 2 \mathrm{H}), 5.72(\mathrm{~s}, 1 \mathrm{H})$, 6.93-6.99 (m, 3H), 7.16-7.21 (m, 4H), 7.28-7.36 (m, $3 \mathrm{H}) ;{ }^{13} \mathrm{C} \mathrm{NMR}\left(100 \mathrm{MHz}, \mathrm{CDCl}_{3}\right) \delta=9.6,26.9,94.1$, $115.9,120.9,125.7,127.2,127.8,128.2,137.1,138.9$, 160.0, 160.9; IR (KBr) 3131, 3036, 2927, 1715, 1642, 1583, 1478, 1393, 1094, 868, 832, 759, $696 \mathrm{~cm}^{-1}$; Anal. Calcd. (\%) for $\mathrm{C}_{17} \mathrm{H}_{16} \mathrm{~N}_{2} \mathrm{O}: \mathrm{C}, 77.25 ; \mathrm{H}, 6.10 ; \mathrm{N}, 10.60$. Found (\%): C, 77.03; H, 6.19; N, 10.49 .

\section{Results and Discussion}

The substrates, $\beta$-oximyl amides $\mathbf{1}$, were prepared by the reaction of $\beta$-oxo amides with hydroxylamine $\left(\mathrm{NH}_{2} \mathrm{OH} \cdot \mathrm{HCl}\right)$ in the presence of $\mathrm{NaOAc}$ in methanol at room temperature in high yields. ${ }^{9}$ We selected $N$-(4chlorophenyl)-1-[1-(hydroxyimino)ethyl]cyclopropane carboxamide 1a as the model compound and examined its behavior in the presence of triflic anhydride. Upon treatment of 1a with triflic anhydride (1.2 equiv.) in dichloromethane (DCM) at room temperature for $60 \mathrm{~min}$, the reaction proceeded as indicated by TLC,

Table 1. Reaction of 1a under different conditions. ${ }^{a}$

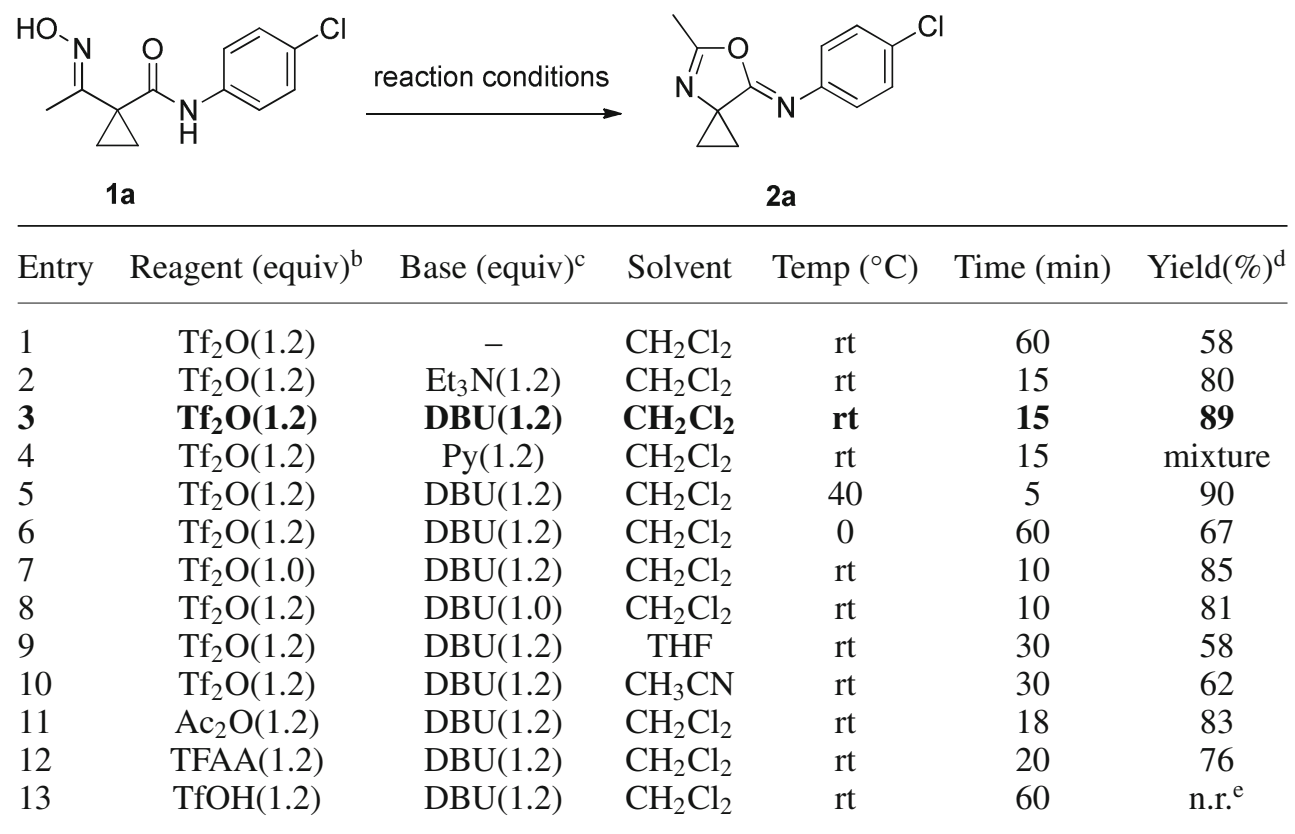

${ }^{\mathrm{a}}$ Reagents and conditions: 1a $(1.0 \mathrm{mmol})$, solvent $(5.0 \mathrm{~mL}) .{ }^{\mathrm{b}}$ TFAA: trifluoroacetic anhydride; $\mathrm{Ac}_{2} \mathrm{O}$ : acetic anhydride; TfOH: trifluoro-methanesulfonic acid. ${ }^{\mathrm{c}} \mathrm{DBU}$ : $1,8-$ diazabicyclo(5.4.0)undec-7-ene; Py: pyridine. ${ }^{\mathrm{d}}$ Isolated yield for $2 \mathbf{2 a} .{ }^{\mathrm{e}}$ No reaction. 
and furnished one product after workup and purification by silica column chromatography. The product was characterized as 4-chloro- $N$-(5-methyl-6-oxa-4azaspiro[2.4]hept-4-en-7-ylidene) aniline 2a based on its spectral and analytical data, (table 1, entry 1). Then, we briefly examined the effect of different acidic/basic reagents and their loaded amounts, solvents, and temperature on the success of the cyclization reaction to $\mathbf{2 a}$. It was found that the yield of 2a could reach $80 \%$ when the reaction was performed with triethylamine $\left(\mathrm{NEt}_{3}\right)$ (table 1, entry 2). Subjecting 1a, $\mathrm{Tf}_{2} \mathrm{O}$ (1.2 equiv.) and DBU (1.2 equiv.) to DCM, the reaction could afford 2a in $89 \%$ yield (table 1 , entry 3 ). However, a complex mixture was formed when the reaction of $\mathbf{1 a}$ and $\mathrm{Tf}_{2} \mathrm{O}$ was conducted in pyridine (table 1, entry 4). Recently, Wray and co-workers discovered that the base played a key role on the reaction of a ketoximes with an adjacent amino group to selectively produce $N$-arylindazoles or benzimidazoles, and the stronger bases favoured the formation of benzimidazole products via the Beckmann rearrangement reaction. ${ }^{13}$ Our results are consistent with their discovery. It was observed that the increase of reaction temperature to $40^{\circ} \mathrm{C}$ had no significant influence on the yield of $\mathbf{2 a}$, but did reduce the reaction time (table 1, entry 5), whereas the reaction required prolonged reaction time along with lower yield when performed at $0^{\circ} \mathrm{C}$ (table 1, entry 6). The decrease of loading of either $\mathrm{Tf}_{2} \mathrm{O}$ or DBU would result in slightly lower yield of $\mathbf{2 a}$ (table 1, entries 7 and 8). The reaction of 1a with $\mathrm{Tf}_{2} \mathrm{O}$ could take place in THF or $\mathrm{CH}_{3} \mathrm{CN}$, but the yields of $\mathbf{2 a}$ were not good in comparison to that in DCM (table 1, entries 9 and 10). The experiments revealed that $\mathrm{Tf}_{2} \mathrm{O}$ was most effective among those tested anhydrides (table 1, entries 11 and 12). No

Table 2. Synthesis of 5-Iminooxazolines $\mathbf{2}$ from $\alpha$ Carbamoyl- $\alpha$-Oximyl Cyclopropanes $\mathbf{1}^{\mathrm{a}}$.

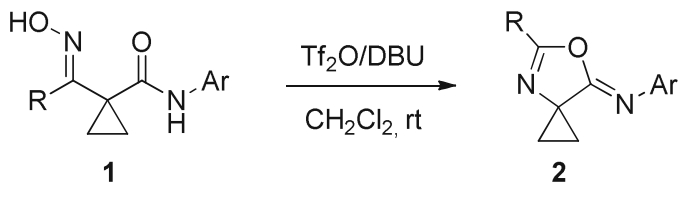

\begin{tabular}{lccccc}
\hline Entry & $\mathbf{1}$ & $\mathrm{Ar}$ & $\mathrm{R}$ & $\mathbf{2}$ & Yield $(\%)^{\mathrm{b}}$ \\
\hline 1 & $\mathbf{1 a}$ & $4-\mathrm{ClC}_{6} \mathrm{H}_{4}$ & $\mathrm{Me}$ & $\mathbf{2 a}$ & 89 \\
2 & $\mathbf{1 b}$ & $3-\mathrm{ClC}_{6} \mathrm{H}_{4}$ & $\mathrm{Me}$ & $\mathbf{2 b}$ & 85 \\
3 & $\mathbf{1 c}$ & $4-\mathrm{MeC}_{6} \mathrm{H}_{4}$ & $\mathrm{Me}$ & $\mathbf{2 c}$ & 83 \\
4 & $\mathbf{1 d}$ & $2,4-\mathrm{Me}_{2} \mathrm{C}_{6} \mathrm{H}_{3}$ & $\mathrm{Me}$ & $\mathbf{2 d}$ & 74 \\
5 & $\mathbf{1 e}$ & $2-\mathrm{MeC}_{6} \mathrm{H}_{4}$ & $\mathrm{Me}$ & $\mathbf{2 e}$ & 75 \\
6 & $\mathbf{1 f}$ & $\mathrm{Ph}_{7}$ & $\mathrm{Me}$ & $\mathbf{2 f}$ & 83 \\
7 & $\mathbf{1 g}$ & $\mathrm{Ph}$ & $\mathrm{Ph}$ & $\mathbf{2 g}$ & 66
\end{tabular}

${ }^{a}$ Reagents and conditions: $1(1.0 \mathrm{mmol}), \mathrm{Tf}_{2} \mathrm{O}(1.2 \mathrm{mmol})$, DBU (1.2 mmol), DCM (5.0 mL), r.t., 15-30 min. ${ }^{\text {b} I s o l a t e d ~}$ yield. reaction was even observed when 1a was subjected to TfOH (table 1, entry13).

Under the conditions as for 2a in entry 3 (table 1), a series of reactions of $\alpha$-carbamoyl- $\alpha$-oximyl cyclopropanes 1 and $\mathrm{Tf}_{2} \mathrm{O}$ and DBU were carried out, and some of the results are listed in table 2 . It was observed that the reactions of $\alpha$-carbamoyl- $\alpha$-oximyl cyclopropanes 1b-f bearing varied electron-withdrawing and electrondonating aryl amide groups proceeded efficiently to afford the corresponding 5-iminooxazolines $\mathbf{2 b - f}$ in good to high yields (table 2, entries 2-6). The versatility of the 5-iminooxazoline synthesis was further evaluated by reacting $1 \mathrm{~g}$ bearing phenyl group $\mathrm{R}$ with $\mathrm{Tf}_{2} \mathrm{O}$ and DBU in DCM (table 2, entry 7). The structure of 2a was further elucidated by X-ray single crystal analysis as shown in figure 1. It should be mentioned that most recently $\mathrm{Li}$ and co-workers conducted the reaction of $\alpha$ carbamoyl- $\alpha$-oximyl cyclopropanes in the presence of DAST (diethylaminosulfur trifluride), and obtained the same compound $\mathbf{2 a} .^{14}$

The efficiency of the synthesis of 5-iminooxazolines 2 was next examined by subjecting $\alpha, \alpha$-disubstituted $\beta$-oximyl amides $\mathbf{1 h}$-l to the cyclization reaction under identical conditions. It was found that the reactions could furnish the corresponding 5-iminooxazolines $\mathbf{2 h}$ $\mathbf{l}$ in good to high yields (table 3 , entries 1-5). To the best of our knowledge, this is the first example for the triflic anhydride-mediated Beckmann Rearrangement reaction of ketoximes. In comparison to the conventio nal Beckmann rearrangement reaction of ketoximes, our protocol is associated with very mild conditions, such as room temperature, short reaction time of less than an hour, simple execution and no strong acid was required.

To expand the general applicability of the synthesis of 5-iminooxazolines 2 , we also carried out the reaction of $\alpha$-monosubstituted $\beta$-oximyl amides $\mathbf{1 m}$ in the same fashion. The reaction could proceed smoothly and furnished a product, which was characterized as 4-benzyl-2-methyl- $N$-phenyloxazol-5-amine 3m based on its spectral and analytical data (scheme 2). Obviously, product $\mathbf{3 m}$ is the isomer of the corresponding

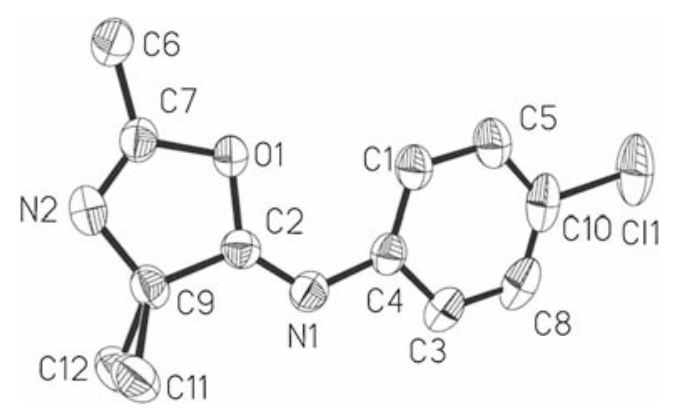

Figure 1. ORTEP drawing of $\mathbf{2 a}$. 
Table 3. Synthesis of 5-iminooxazolines 2 from $\alpha, \alpha$ Disubstituted $\beta$-Oximyl Amides 1. ${ }^{\mathrm{a}}$

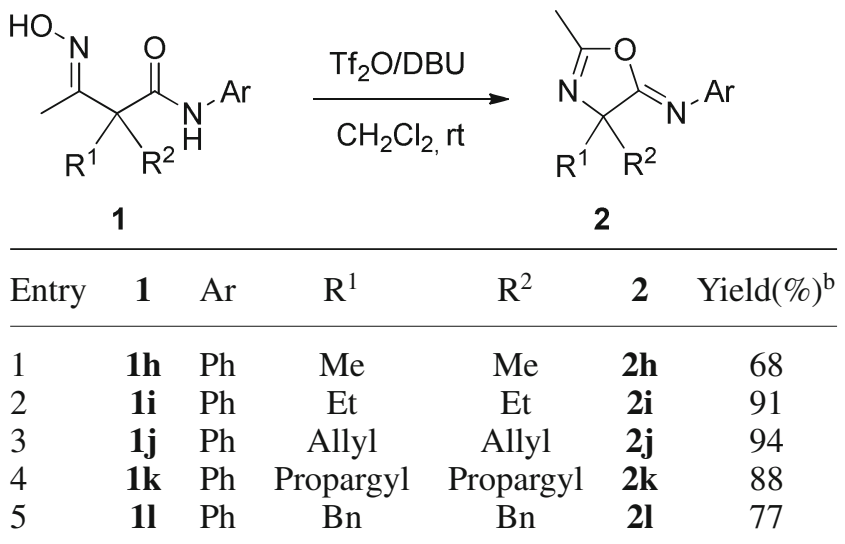

${ }^{a}$ Reagents and conditions: 1 (1.0 mmol), $\mathrm{Tf}_{2} \mathrm{O}(1.2 \mathrm{mmol})$, DBU (1.2 mmol), DCM (5.0 mL), r.t., 15-30 min. ${ }^{b}$ Isolated yield.

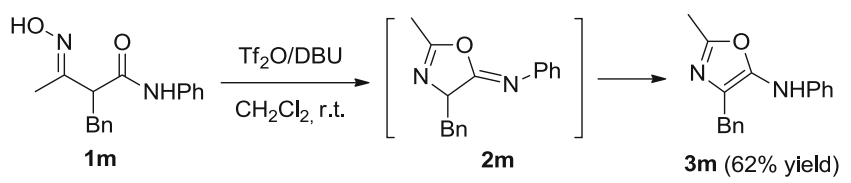

Scheme 2. The reaction of $\mathbf{1 m}$ with $\mathrm{Tf}_{2} \mathrm{O}$ in DCM.

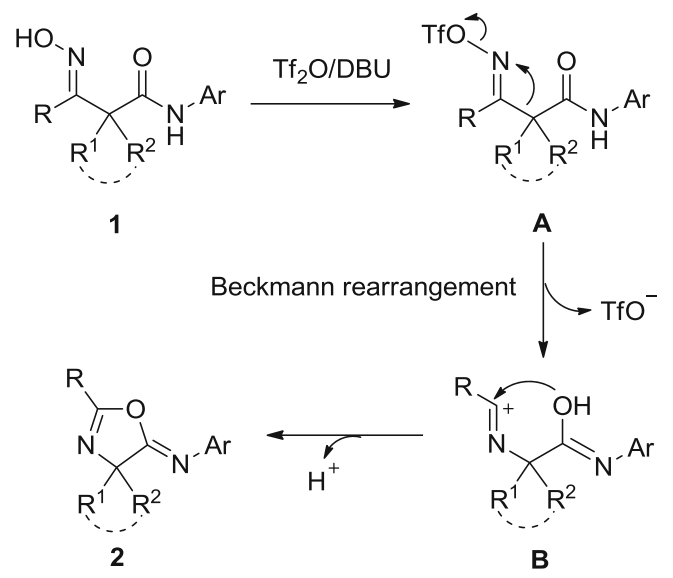

Scheme 3. Plausible mechanism for the reaction of $\mathbf{1}$ with $\mathrm{Tf}_{2} \mathrm{O}$ in DCM.

5-iminooxazoline $\mathbf{2 m}$. Therefore, we provided herewith an alternative synthetic route to 5-iminooxazolines 2 and 5-aminooxazoles $\mathbf{3}$. Actually, oxazoline unit is the core moiety present in numerous natural products and synthetic organic compounds along with a variety of biological activities, such as melatonin receptor agonist, antimycobacterial, anticancer, and elastase inhibitor agents. ${ }^{15-17}$

On the basis of the above experimental results together with some literature reports, ${ }^{18,19}$ a mechanism for the synthesis of 5-Iminooxazolines $\mathbf{2}$ is proposed as depicted in scheme 3. In the presence of DBU, tosylation of $\beta$-oximyl amide 1 occurs to give an intermediate $\mathbf{A},{ }^{18}$ which undergoes the Beckmann rearrangement reaction to afford intermediate $\mathbf{B},{ }^{19}$ followed by intramolecular cyclization to form substituted 5iminooxazoline of type $\mathbf{2}$.

\section{Conclusions}

In summary, a facile and efficient one-pot synthesis of 5-iminooxazolines $\mathbf{2}$ is developed via triflic anhydridemediated Beckmann rearrangement reaction of readily available $\beta$-oximyl amides $\mathbf{1}$. The protocol was successfully expanded to the synthesis of 5-aminooxazoles $\mathbf{3}$. The ready availability of substrates, mild reaction conditions, simple execution, and synthetic potential of the products make this novel protocol very attractive.

\section{Supplementary Information (SI)}

Copies of NMR spectra for products $\mathbf{2}$ and $\mathbf{3}$ are available at www.ias.ac.in/chemsci. CCDC deposition number: 1063953. The crystallographic data can be obtained free of charge via www.ccdc.cam.ac.uk/conts/ retrieving.html (or from the Cambridge Crystallographic Data Center, 12 Union Road, Cambridge CB21EZ, UK; fax: (+44) 1223336 033; or deposit@ccdc.cam. ac.uk).

\section{Acknowledgements}

Financial support for this research by the National Natural Science Foundation of China (21172211 and 21542006) are greatly acknowledged.

\section{References}

1. (a) Gawley R E 1988 Org. React. 35 1; (b) Donaruma L G and Heldt W Z 1960 Org. React. 11 1; (c) McCarty C G 1970 In The Chemistry of the CarbonNitrogen Double Bond S Patai (Ed.) (New York: WileyInterscience) pp. 408-439; (d) Hauske J R 1991 Comp. Org. Syn. 1 77; (e) Maruoka K and Yamamoto H 1991 Comp. Org. Syn. 6 763; (f) Craig D 1991 Comp. Org. Syn. 7 689; (g) Blatt H 1933 Chem. Rev. 12215

2. (a) Luedeke V D 1978 In Encyclopedia of Chemical Processing and Design J J Mcketta (Ed.) (New York: Marcel Dekker) pp. 72-95; (b) Rademacher H 1987 In Ullmann's Encyclopedia of Industrial Chemistry Vol. A8 5th ed., W Gerhartz (Ed.) (New York: Wiley) pp. 201-203; (c) Weber J N 1990 In Kirk-Othmer Encyclopedia of Chemical Technology Vol. 19, 4th ed., J I Kroschwitz (Ed.) (New York: Wiley) pp. 500-501; (d) Wessermel K and Arpe H -J 2003 In Industrial Organic Chemistry, 4th ed. (Weinheim, Germany: Wiley- $\mathrm{VcH}$ ) pp. $239-266$ 
3. (a) Kopple K D and Katz J J 1959 J. Org. Chem. 24 1975; (b) Sato H, Yoshioka H and Izumi Y 1999 J. Mol. Catal. A: Chem. 14925

4. (a) Hashimoto M, Obora Y, Sakaguchi S and Ishii Y 2008 J. Org. Chem. 73 2894; (b) Pi H-J, Dong D, An N, Du W and Deng W -P 2009 Tetrahedron 657790

5. (a) Yadav L D S, Patel R and Srivastava V P 2010 Synthesis 1771; (b) Srivastava V P, Patel R, Garima and Yadav L D S 2010 Chem. Commun. 465808

6. (a) Zhu M, Cha C, Deng W -P and Shi X -X 2006 Tetrahedron Lett. 47 4861; (b) Furuya Y, Ishihara K and Yamamoto H 2005 J. Am. Chem. Soc. 127 11240; (c) Augustine J K, Kumar R, Bombrun A and Mandal A B 2011 Tetrahedron Lett. 521074

7. (a) Peng J and Deng Y 2001 Tetrahedron Lett. 42 403; (b) Ren R X, Zueva L D and Ou W 2001 Tetrahedron Lett. 42 8441; (c) Guo S, Du Z, Zhang S, Li D, Li Z and Deng Y 2006 Green Chem. 8 296; (d) Gui J, Deng Y Hu Z and Sun Z 2004 Tetrahedron Lett. 452681

8. (a) Ikushima Y, Hatakeda K, Sato O, Yokoyama T and Arai M 2000 J. Am. Chem. Soc. 122 1908; (b) Sato O Ikushima Y and Yokoyama T 1998 J. Org. Chem. 63 9100; (c) Boero M, Ikeshoji T, Liew C C, Terakura K and Parrinello M 2004 J. Am. Chem. Soc. 1266280

9. Wang K, Xiang D, Liu J, Pan W and Dong D 2008 Org. Lett. 101691

10. Fu X, Huang P, Zhou G, Hu Y and Dong D 2011 Tetrahedron 676347
11. (a) Sardarian A R, Shahsavari-Fard Z, Shahsavari H R and Ebrahimi Z 2007 Tetrahedron Lett. 48 2639; (b) Tian B -X, An N, Deng W -P and Eriksson L A 2013 J. Org. Chem. 78 6782; (c) Rawlings B J, Reese P B, Ramer S E and Vederas J C 1989 J. Am. Chem. Soc. 1113382

12. Huang P, Zhang N, Zhang R and Dong D 2012 Org. Lett. 14370

13. (a) Counceller C M, Eichman C C, Wray B C and Stambuli J P 2008 Org. Lett. 10 1021; (b) Wray B C and Stambuli J P 2010 Org. Lett. 124576

14. Li H, Qin J, Yang Z, Guan X, Zhang L, Liao P and Li X 2015 Chem. Commum. 518637

15. (a) Sadjadi S and Heravi M M 2011 Tetrahedron 67 2707; (b) Kaim L E, Grimaud L and Schiltz A 2009 Tetrahedron Lett. 50 5235; (c) Baumann M, Baxendale I R, Ley S V, Smith C D and Tranmer G K 2006 Org. Lett. 85231

16. (a) Esmaeili A A, Shahmansouri S, Habibi A and Fakhari A R 2012 Tetrahedron 68 8046; (b) Bughin C, Zhao G, Bienaymé H and Zhu J 2006 Chem. Eur. J. 12 1174

17. Dunbar K L and Mitchell D A 2013 J. Am. Chem. Soc. 1358692

18. (a) Campbell Jr. J B and Davenport T W 1989 Synth. Commun. 19 2255; (b) Kodama S, Okamura H and Shirai M 2012 Chem. Lett. 41625

19. (a) Fodor G and Nagubandi S 1980 Tetrahedron 36 1279; (b) De Luca L, Giacomelli G and Porcheddu A 2002 J. Org. Chem. 676272 